\title{
PENGEMBANGAN PERANGKAT PEMBELAJARAN TEOREMA PYTHAGORAS DENGAN MEDIA BERBANTUAN KOMPUTER
}

\author{
Erni Ayda ${ }^{1)}$, Djamilah Bondan Widjajanti ${ }^{2)}$ \\ SMP Negeri 3 Banyubiru ${ }^{1)}$, Universitas Negeri Yogyakarta ${ }^{2)}$ \\ ayda.erni@yahoo.com ${ }^{1)}$,dj_bondan@yahoo.com ${ }^{2)}$
}

\begin{abstract}
Abstrak
Penelitian ini bertujuan untuk menghasilkan perangkat pembelajaran matematika SMP dengan media berbantuan komputer pada materi teorema Pythagoras yang valid, praktis, dan efektif ditinjau dari prestasi belajar matematika dan mathematics self-efficacy siswa. Penelitian ini merupakan penelitian pengembangan yang terdiri atas empat tahap, yaitu tahap define, design, develop, dan disseminate. Subjek coba dalam penelitian ini terdiri atas 9 siswa untuk uji coba kelompok kecil dan 30 siswa untuk uji coba lapangan. Penelitian dilaksanakan di SMP Negeri 2 Banyubiru, Kabupaten Semarang. Instrumen penelitian yang digunakan adalah lembar validasi, lembar penilaian guru, lembar penilaian siswa, lembar observasi kegiatan guru, lembar observasi kegiatan siswa, dan kuesioner mathematics selfefficacy. Kriteria keberhasilan dalam penelitian ini adalah jika banyaknya siswa yang memperoleh nilai tes akhir melebihi KKM lebih dari $75 \%$ dan siswa yang memiliki skor mathematics self-efficacy pada kriteria tinggi atau sangat tinggi lebih dari 75\%. Hasil penelitian menunjukkan bahwa perangkat pembelajaran yang dikembangkan adalah valid, praktis, dan efektif ditinjau dari prestasi siswa dan skor mathematics self-efficacy mereka.
\end{abstract}

Kata kunci: pengembangan, silabus, RPP, LKS, media, prestasi belajar siswa, mathematics selfefficacy.

\section{DEVELOPING A TEACHING KIT ON PYTHAGOREAN THEOREM WITH COMPUTER-ASSISTED MEDIA}

\begin{abstract}
This research is conducted in order to set up a mathematics teaching kit for junior high school on Pythagorean theorem material with computer-assisted media, which is valid, practical, and effective in terms of students' learning achievement and mathematics self-efficacy. This research is a developmental research consisting of four phases: define, design, develop, and disseminate. The subjects consisted of two groups: nine students in the small trial group and 30 students in the field trial group. The experiment was conducted at SMP Negeri 2 Banyubiru, Kabupaten Semarang. The instruments used in this research was a validation sheet, teacher assessment sheet, student assessment sheet, teacher activities observation sheet, student's activities observation sheet, and mathematics selfefficacy questionnaire. The criteria for success were if the number of students who received the final test scores exceeded the minimum achievement criterion was more than $75 \%$ and the number of students who had mathematics self-efficacy score in high or very high criteria was more than $75 \%$. The results show that the developed teaching kit is valid, practical, and effective in terms of students' achievement and mathematics self-efficacy scores.
\end{abstract}

Keywords: development, syllabus, lesson plans, worksheet, media, student achievement, mathematics self-efficacy. 


\section{PENDAHULUAN}

Pelajaran matematika merupakan salah satu mata pelajaran yang memiliki manfaat besar dalam kehidupan. Matematika memberikan kesempatan kepada siswa untuk melatih mental mereka dan akan berpengaruh terhadap perkembangan intelektual mereka. Melalui pelajaran matematika siswa akan mampu belajar untuk memperoleh pengetahuan secara sistematis (Sunnetha, 2011, p.70).

Namun demikian, prestasi belajar siswa dalam pelajaran matematika masih rendah. Padahal prestasi belajar adalah salah satu aspek penting dalam pendidikan di sekolah yang tidak dapat dipisahkan dari kehidupan siswa (Tamuri, 2005, p.23). Rendahnya prestasi belajar siswa, terutama pada mata pelajaran matematika, terjadi pada sebagian besar materi yang diajarkan. Salah satunya adalah materi teorema Pythagoras. Hal ini didasarkan pada kenyataan di lapangan bahwa pada materi ini daya serap siswa pada hasil Ujian Nasional masih menunjukkan angka yang relatif rendah, termasuk yang terjadi di SMP Negeri 2 Banyubiru.

Permasalahan rendahnya prestasi belajar matematika siswa terutama pada materi teorema Pythagoras merupakan masalah yang sangat penting untuk diatasi. Hal ini disebabkan oleh urgenitas dari materi tersebut sebagai salah satu materi prasyarat bagi pokok bahasan lain dalam pelajaran matematika. Meskipun materi ini merupakan materi prasyarat untuk materi yang lain, namun berdasarkan hasil pengamatan guru di kelas, ketika pelajaran matematika pada umumnya beberapa siswa kurang begitu tertarik pada pelajaran yang disampaikan guru. Kondisi ini mengindikasikan bahwa pembelajaran matematika di kelas kurang menarik. Oleh karenanya perlu dilakukan upaya pelaksanaan pembelajaran yang menyenangkan.

Pembelajaran yang menyenangkan dapat meningkatkan prestasi belajar siswa dalam pembelajaran matematika, yang merupakan tujuan utama yang harus dilakukan guru di sekolah. Guru mempunyai tangggung jawab dan kewajiban yang besar dalam mengembangkan dan menciptakan suasana pendidikan yang bermakna, menyenangkan, kreatif, dinamis, dan dialogis. Pengembangan proses belajar dan mengajar tersebut hendaknya mengarah pada pembelajaran bermakna sehingga dapat meningkatkan sikap dan minat siswa terhadap matematika.

Salah satu pelaksanaan pembelajaran bermakna dapat dilakukan dengan penggunaan pendekatan pembelajaran kontekstual atau disebut sebagai contextual teaching and learning (CTL). Contextual Teaching and Learning (CTL) merupakan pendekatan pembelajaran yang membuat siswa dapat menghubungkan isi dari subjek-subjek akademik dengan konteks kehidupan keseharian mereka yaitu konteks keadaan pribadi, sosial, dan budaya mereka, untuk menemukan makna (Johnson, 2010, p.59). Sintaks dalam pelaksanan CTL disingkat sebagai REACT, yaitu relating, experiencing, applying, cooperating, dan transferring (Crawford, 2001, p.3; Souders, 1999; Masnur, 2008, p.41). Relating adalah belajar dalam konteks pengalaman hidup seseorang atau pengetahuan yang telah ada. Experiencing adalah belajar dengan melakukan (learning by doing) melalui eksplorasi (exploration), menemukan sesuatu yang sudah ada (discovery), dan penemuan hal baru (invention). Applying adalah belajar dengan menggunakan konsep dengan melakukan latihan menggunakan materi yang realistik dan relevan. Cooperating adalah belajar dalam konteks berbagi, menanggapi, dan berkomunikasi dengan siswa lain. Transferring adalah kegiatan menggunakan pengetahuan dalam konteks atau situasi baru atau memindahkan, menggunakan, dan membangun sesuatu pengetahuan berdasarkan apa yang telah diketahui siswa.

Pendekatan pembelajaran kontekstual dilakukan dengan menghubungkan atau mengaitkan antara pengetahuan yang telah dimiliki siswa dengan pengetahuan yang baru. Melalui pembelajaran bermakna yaitu pendekatan pembelajaran kontekstual diharapkan siswa akan memiliki pemahaman yang lebih baik terhadap materi pelajaran yang mereka pelajari. Pemahaman yang baik akan menumbuhkan rasa kepercayaan diri siswa atau keyakinan mereka akan kemampuannya dalam belajar matematika.

Keyakinan diri akan kemampuan belajar matematika disebut sebagai mathematics self-efficacy. Siswa yang memiliki mathematics self-efficacy lebih tinggi akan mampu menyelesaikan masalah matematika dengan lebih baik (Zimmermann, 2011, p.3). Keyakinan seseorang akan kompetensi matematikanya (baik keterampilan maupun pengetahuan) adalah faktor penting untuk mencapai sukses dalam pembelajaran matematika.

Tait (2008, p.507) menyebutkan bahwa bagi guru matematika, wawasan mengenai selfefficacy siswa merupakan alat yang berharga. Tait menyebutkan bahwa "it is important for educators to know how their learners feel, 
thonk, and act, about, within, and toward mathematics". Self-efficacy memiliki potensi untuk memfasilitasi atau menghambat motivasi belajar matematika, penggunaan pengetahuan, dan pengaturan untuk belajar.

Zimmermann (2011, p.3) menyebutkan bahwa mathematics self-efficacy adalah keyakinan seseorang terhadap kompetensinya masing-masing untuk menyelesaikan masalah dan tugas matematika dengan sukses ("mathematics self-efficacy indicate the belief of a person in his/her own competence to solve mathematical problems and tasks successfully"). Lebih lanjut, Hackett \& Betz (Sengul, 2011, p.2305) mendefinisikan "mathematics self-efficacy as an individual's confidence in her or his ability to successfully perform or accomplish a mathematics task". Hal yang sama diungkapkan oleh Anjum (2006, p.63) yaitu bahwa mathematics self-efficacy adalah keputusan seseorang mengenai kemampuannya dalam menyelesaikan masalah matematika secara khusus ("mathematics self-efficacy was defined as an individual's judgement of his/her capabilities to solve specific mathematics problems"). Keyakinan terhadap kemampuan diri adalah hal yang penting dalam pencapaian prestasi belajar siswa dibidang matematika (Liu, 2009, p.9). Ada empat konsep yang dapat diukur untuk menentukan mathematics self-efficacy adalah performance accomplishments, vicarious experiences, verbal persuasion, dan physiological and emotional states (Bandura, 1995, p.3; Bandura, 1977, p.195, Margolis \& McCabe, 2006, p.219).

Berdasarkan pengamatan peneliti melalui studi pendahuluan menunjukkan bahwa mathematics self-efficacy siswa di SMP Negeri 2 Banyubiru ada pada kriteria sedang. Permasalahan pencapaian prestasi belajar siswa yang masih relatif rendah khususnya pada materi teorema Pythagoras dan pentingnya meningkatkan skor mathematics self-efficacy perlu diatasi agar tujuan pembelajaran matematika dapat dipenuhi. Salah satu upaya yang dapat dilakukan untuk mengatasi kedua masalah tersebut dan menjadikan pelajaran matematika di kelas menjadi lebih menyenangkan adalah dengan melibatkan teknologi khususnya komputer. Penggunaan komputer dalam pembelajaran dapat membantu siswa untuk mengembangkan kemampuan dasar dan keterampilan berpikir kritis (Moore, 2009, p.53).

Berdasarkan pemaparan di atas, tujuan penelitian ini adalah untuk menghasilkan perangkat pembelajaran matematika SMP dengan media berbantuan komputer pada materi teorema Pythagoras yang valid, praktis, dan efektif ditinjau dari prestasi belajar matematika dan mathematics self-efficacy siswa.

Pengembangan perangkat pembelajaran dalam penelitian ini meliputi silabus, RPP, LKS, dan media pembelajaran berbantuan komputer. Perangkat pembelajaran yang dikembangkan dilengkapi dengan instrumen tes akhir dan instrumen mathematics self-efficacy yang digunakan untuk menentukan keefektifan produk hasil pengembangan. Perangkat pembelajaran adalah sekumpulan sumber belajar yang memungkinkan guru dan siswa melakukan kegiatan pembelajaran. Perangkat pembelajaran dirancang dan disusun untuk menunjang pelaksanaan proses pembelajaran sehingga dapat dilaksanakan dengan baik dan dapat mencapai tujuan yang diharapkan (Omrod, 2003, p.429).

Materi pelajaran yang digunakan adalah materi teorema Pythagoras untuk siswa kelas VIII SMP. Menurut Skemp (1971, p.216), "Pythagoreas' theorem: that in any right-angled triangle, if we draw squares on the three sides, the area of the square on the hypotenuse (the side opposite the right angle) is equal to the sum of the areas of the square on the other two sides". Dalam teorema Pythagoras berlaku bahwa untuk sembarang segitiga siku-siku, jika digambarkan persegi pada ketiga sisinya, luas persegi pada hipotenusa (sisi yang berhadapan dengan sudut siku-siku) adalah sama dengan jumlah luas persegi pada kedua sisi yang lain.

\section{METODE}

\section{Jenis Penelitian}

Penelitian ini termasuk jenis research and development atau jenis penelitian dan pengembangan. Pengembangan dalam penelitian ini adalah pengembangan perangkat pembelajaran matematika dengan media berbantuan komputer pada SK 3 kelas VIII yaitu materi teorema Pythagoras. Perangkat yang dikembangkan meliputi Silabus, RPP, Lembar Kegiatan Siswa, dan Media pembelajaran yang menggunakan Macromedia Flash 8. Model pengembangan pembelajaran untuk menghasilkan perangkat pembelajaran yang digunakan dalam penelitian ini adalah model 4-D dari Thiagarajan, Semmel, dan Semmel. 


\section{Waktu dan Tempat Penelitian}

Penelitian dilaksanakan pada bulan Oktober-Nopember 2013 di SMP Negeri 2 Banyubiru Kabupaten Semarang.

\section{Subjek Penelitian}

Subjek coba dalam penelitian ini adalah siswa kelas VIII SMP Negeri 2 Banyubiru. Pemilihan subjek coba dilakukan dengan memilih secara acak pada 9 siswa untuk uji coba kelompok kecil dan satu kelas coba dari lima kelas yang ada untuk uji coba lapangan. Sembilan siswa untuk uji coba kelompok kecil adalah siswa kelas VIII B dan uji coba lapangan dilakukan pada siswa kelas VIII E.

\section{Prosedur Pengembangan}

Prosedur pengembangan dalam penelitian ini terdiri dari 4-D, yang dijelaskan secara terperinci dalam langkah-langkah sebagai berikut.

\section{Define (Pendefinisian)}

Tujuan tahap ini adalah menetapkan dan mendefinisikan syarat-syarat pembelajaran. Penetapan dan pendefinisian syarat-syarat pembelajaran diawali dengan analisis tujuan dan batasan materi yang dikembangkan perangkatnya. Tahap ini meliputi lima langkah pokok, yaitu: analisis awal akhir; analisis siswa; analisis tugas; analisis konsep; dan perumusan tujuan pembelajaran.

\section{Design (Perancangan)}

Empat langkah dalam tahap design yaitu penyusunan tes kriteria, pemilihan media, pemilihan format, dan rancangan awal. Penyusunan tes kriteria dalam bentuk tes akhir berdasarkan hasil perumusan tujuan pembelajaran dalam penelitian ini adalah penyusunan tes prestasi belajar siswa.

\section{Develop (Pengembangan)}

Pada tahap develop dilakukan validasi oleh ahli terhadap perangkat pembelajaran dan instrumen-instrumen draf 1 yang telah disusun pada tahap sebelumnya. Revisi draf 1 yang dilakukan berdasarkan masukan dan saran validator digunakan untuk melaksanakan uji coba kelompok kecil. Uji coba kelompok kecil dilakukan terhadap sembilan siswa yang melakukan penilaian serta memberikan saran untuk merevisi perangkat pembelajaran hasil pengembangan. Selain siswa, guru juga memberikan penilaian serta masukan untuk memperbaiki perangkat pembelajaran. Hasil revisi pada tahap ini disebut sebagai draf 2 yang akan digunakan untuk uji coba lapangan.

Uji coba lapangan dilakukan pada kelas VIIIE yang dipilih secara acak dari lima kelas VIII yang ada di SMP N 2 Banyubiru. Uji coba lapangan dilaksanakan dalam tujuh pertemuan sebagai mana telah direncanakan dalam RPP dan ditutup dengan kegiatan tes akhir dan pengisian kuesioner mathematics self-efficacy pada pertemuan kedelapan. Hasil tes akhir dan mathematics self-efficacy dianalisis untuk mengetahui keefektifan perangkat pembelajaran yang dikembangkan. Jika kriteria keefektifan telah terpenuhi maka draf 2 telah dapat dipakai sebagai perangkat final. Namun jika belum efektif maka masih harus dilakukan revisi dan dilakukan uji coba lapangan kembali.

\section{Disseminate (Penyebaran)}

Disseminate merupakan tahap akhir dari pengembangan perangkat pembelajaran model 4-D. Perangkat pembelajaran yang telah dikembangkan menjadi perangkat final siap digunakan atau diterapkan pada kelas yang lain. Namun dalam penelitian ini tahap penyebaran tidak dilaksanakan.

\section{Data dan Instrumen Penelitian}

Data dalam penelitian ini adalah data kualitatif dan data kuantitatif. Data kualitatif diperoleh dari hasil angket mathematics selfefficacy, sedangkan data kuantitatif diperoleh dari prestasi tes akhir. Instrumen penelitian yang dikembangkan dalam penelitian ini diklasifikasikan menjadi tiga macam yang masing-masing digunakan untuk memenuhi kriteria valid, praktis, dan efektif ditinjau dari prestasi belajar dan skor mathematics self-efficacy siswa.

Instrumen untuk mengukur kevalidan berupa lembar validasi silabus, RPP, LKS, dan media, serta lembar validasi instrumen tes akhir dan instrumen mathematics self-efficacy. Instrumen untuk mengukur kepraktisan berupa lembar penilaian guru, lembar observasi pelaksanaan pembelajaran, dan lembar penilaian untuk siswa yang digunakan dalam uji coba kelompok kecil dan uji coba lapangan. Instrumen untuk mengukur keefektifan perangkat pembelajaran hasil pengembangan berupa instrumen tes akhir dan dan instrumen mathematics self-efficacy. 


\section{Teknik Analisis Data}

Analisis Kevalidan Perangkat Pembelajaran dan Instrumen Mathematics Self-Efficacy

Perangkat pembelajaran yaitu silabus, RPP, LKS, dan media dan instrumen mathematics self-efficacy yang sudah divalidasi ahli selanjutnya dianalisis secara deskriptif atau kualitatif. Langkah-langkah yang dilakukan untuk menganalisis data dengan menggunakan teknik statistik deskriptif.

\section{Analisis Kepraktisan}

Analisis kepraktisan dilakukan terhadap data penilaian guru, data hasil pengisian lembar observasi kegiatan pembelajaran, dan data penilaian siswa pada uji coba kelompok kecil dan uji coba lapangan.

\section{Analisis Keefektifan Pembelajaran}

Analisis keefektifan dilakukan terhadap hasil tes akhir sebagai prestasi belajar siswa dan hasil pengisian angket mathematics self-efficacy.

\section{HASIL DAN PEMBAHASAN}

\section{Hasil Pengembangan}

Hasil pengembangan dalam penelitian ini adalah perangkat pembelajaran dengan media berbantuan komputer yang valid, praktis, dan efektif ditinjau dari prestasi belajar siswa dan skor mathematics self efficacy. Perangkat pembelajaran yang dikembangkan yaitu silabus, RPP, LKS, dan media pembelajaran berbantuan komputer.

Validasi perangkat pembelajaran dilakukan oleh dua orang validator sebagai ahli yang memberikan penilaian terhadap perangkat pembelajaran yang dikembangkan serta memberikan masukan atau saran perbaikan. Pada akhirnya diperoleh hasil pengembangan perangkat pembelajaran berupa silabus, RPP, LKS, dan media pembelajaran berbantuan komputer yang valid. Secara keseluruhan penilaian terhadap perangkat pembelajaran yang dikembangkan adalah pada kategori valid dan sangat valid.

Penilaian kepraktisan produk dilakukan berdasarkan penilaian oleh praktisi yaitu guru, dalam hal ini dilakukan oleh dua orang guru matematika di SMP Negeri 2 Banyubiru. Selain penilaian oleh praktisi, kepraktisan produk juga dinilai berdasarkan penilaian siswa terhadap LKS, instrumen tes akhir, dan media pembelajaran berbantuan komputer yang dikembangkan. Berdasarkan angket yang telah diisi siswa, perangkat pembelajaran yang dikembangkan memiliki kriteria praktis. Hasil observasi guru terhadap kegiatan guru dan siswa juga menunjukkan bahwa perangkat pembelajaran hasil pengembangan dalam penelitian ini adalah praktis untuk digunakan di lapangan.

Keefektifan perangkat pembelajaran yang dikembangkan ditinjau dari prestasi belajar siswa dan mathematics self-efficacy menunjukkan kriteria efektif. Lebih dari $75 \%$ siswa telah mencapai atau melampaui KKM yang ditetapkan. Selain itu, siswa yang memiliki skor mathematics self-efficacy dengan kategori tinggi atau sangat tinggi adalah sebesar $83,34 \%$, hal ini berarti telah melebihi $75 \%$ sesuai dengan kriteria keberhasilan pengembangan yang telah ditetapkan.

Proses pengembangan perangkat pembelajaran dalam penelitian ini dilakukan dalam empat tahap yang meliputi kegiatan define (pendefinisian), design (perancangan), develop (pengembangan), dan disseminate (penyebaran). Pada akhirnya telah dihasilkan perangkat pembelajaran matematika dengan media berbantuan komputer yang valid, praktis, dan efektif ditinjau dari prestasi belajar siswa dan skor mathematics self-efficacy.

\section{Hasil Uji Coba Produk}

\section{Data Hasil Validasi Ahli}

Ahli yang melakukan validasi perangkat pembelajaran dalam penelitian ini adalah dosen pendidikan matematika berjumlah dua orang. Perbaikan dilakukan berdasarkan masukan dan saran yang diberikan oleh validator. Hasil penilaian oleh validasi terhadap Silabus, RPP, LKS, dan media pembelajaran berbantuan komputer disajikan dalam Tabel 1 berikut.

Tabel 1. Skor Hasil Validasi Ahli

\begin{tabular}{|c|c|c|c|c|}
\hline Produk & $\begin{array}{c}\text { Skor } \\
\text { Maks }\end{array}$ & $\begin{array}{c}\text { Validator } \\
1\end{array}$ & $\begin{array}{c}\text { Validator } \\
2\end{array}$ & $\begin{array}{c}\text { Kriteria } \\
\text { Hasil }\end{array}$ \\
\hline Silabus & 125 & 104 & 121 & $\begin{array}{c}\text { Sangat } \\
\text { Valid }\end{array}$ \\
\hline RPP & 200 & 174 & 175 & $\begin{array}{c}\text { Sangat } \\
\text { Valid }\end{array}$ \\
\hline LKS & 160 & 140 & 138 & $\begin{array}{c}\text { Sangat } \\
\text { Valid }\end{array}$ \\
\hline Media & 95 & 88 & 95 & $\begin{array}{c}\text { Sangat } \\
\text { Valid }\end{array}$ \\
\hline
\end{tabular}

Data Hasil Uji Coba Kelompok Kecil

Perangkat pembelajaran yang dinilai oleh guru adalah silabus, RPP, LKS, dan media. Penilaian guru digunakan untuk mengetahui tingkat kepraktisan perangkat pembelajaran yang 
dikembangkan. Hasil penilaian guru pada uji coba kelompok kecil menunjukkan bahwa perangkat pembelajaran hasil pengembangan mempunyai kriteria sangat praktis dengan skor untuk penilai 1 dan penilai 2 berturut-turut adalah 130 dan 123. Hasil penilaian siswa meliputi penilaian terhadap LKS, instrumen tes akhir, dan media adalah tiga siswa memberikan penilaian sangat praktis dan enam lainnya menilai praktis. Hasil observasi kegiatan guru mencapai skor 15 dengan kriteria sangat praktis dan kegiatan siswa mencapai skor 5 dengan kriteria praktis.

\section{Data Hasil Uji Coba Lapangan}

Penilaian guru terhadap perangkat pembelajaran pada uji coba lapangan menunjukkan bahwa silabus, RPP, LKS, dan media hasil pengembangan mempunyai kriteria sangat praktis. Penilaian siswa dilakukan setelah siswa mengikuti keseluruhan proses kegiatan pembelajaran. Siswa diminta memberikan penilaian terhadap LKS, instrumen tes akhir, dan media pembelajaran berbantuan komputer. Hasilnya $30 \%$ siswa menilai sangat praktis dan $70 \%$ menilai praktis.

Hasil observasi pembelajaran yang dilaksanakan dalam tujuh pertemuan pada uji coba lapangan ini berada pada kriteria sangat praktis untuk kegiatan guru baik dari observer 1 maupun observer 2. Skor maksimal yang mungkin dari lembar observasi penilaian guru adalah 15 . Kegiatan siswa berada pada kriteria praktis untuk pertemuan pertama berdasarkan hasil pengamatan lapangan oleh observer 1 . Sedangkan untuk observer 2, hasilnya adalah kriteria praktis untuk pertemuan pertama dan ketiga, serta pertemuan lainnya adalah sangat praktis. Skor maksimal untuk lembar observasi kegiatan siswa adalah 8 .

Hasil tes akhir menunjukkan bahwa sebanyak 23 dari 30 siswa atau sebesar 76,67\% siswa telah mencapai KKM. Hasil skor mathematics self-efficacy menunjukkan bahwa sebanyak $6,67 \%$ siswa mempunyai skor pada kriteria sangat tinggi, 76,67\% kriteria tinggi, dan $16,67 \%$ kriteria sedang.

\section{Analisis Data Hasil Uji Coba}

\section{Analisis Data Hasil Validasi Ahli}

Data hasil validasi ahli secara keseluruhan menunjukkan bahwa silabus yang telah dikembangkan mempunyai kategori sangat valid baik berdasarkan penilaian validator 1 maupun validator 2. Hasil penilaian validator tersebut dapat diperinci menjadi penilaian berdasarkan masing-masing aspek dari setiap butir pernyataan. Analisis untuk masing-masing aspek pada silabus dapat dilihat pada Tabel 2 berikut ini.

Tabel 2. Proses Validasi Silabus Berdasarkan Aspek yang Dinilai

\begin{tabular}{|c|c|c|c|}
\hline Aspek yang Dinilai & $\begin{array}{l}\text { Skor } \\
\text { Maks }\end{array}$ & Skor & Kriteria \\
\hline $\begin{array}{c}\text { Perumusan Standar } \\
\text { Kompetensi dan } \\
\text { Kompetensi Dasar }\end{array}$ & 50 & 46 & $\begin{array}{l}\text { Sangat } \\
\text { Valid }\end{array}$ \\
\hline Materi Pembelajaran & 40 & 35 & $\begin{array}{l}\text { Sangat } \\
\text { Valid }\end{array}$ \\
\hline Kegiatan Pembelajaran & 40 & 33 & $\begin{array}{l}\text { Sangat } \\
\text { Valid }\end{array}$ \\
\hline $\begin{array}{c}\text { Indikator Pencapaian } \\
\text { Kompetensi }\end{array}$ & 40 & 35 & $\begin{array}{l}\text { Sangat } \\
\text { Valid }\end{array}$ \\
\hline Penilaian & 30 & 27 & $\begin{array}{l}\text { Sangat } \\
\text { Valid }\end{array}$ \\
\hline Alokasi Waktu & 20 & 20 & $\begin{array}{l}\text { Sangat } \\
\text { Valid }\end{array}$ \\
\hline $\begin{array}{c}\text { Sumber Belajar/Media } \\
\text { Pembelajaran }\end{array}$ & 30 & 29 & $\begin{array}{l}\text { Sangat } \\
\text { Valid }\end{array}$ \\
\hline
\end{tabular}

Hasil validasi RPP yang telah dilakukan oleh validator menunjukkan bahwa RPP hasil pengembangan mempunyai kategori sangat valid. Secara lebih jelas, rincian hasil validasi RPP untuk setiap aspek penilaian disajikan dalam Tabel 3 berikut.

Tabel 3. Proses Validasi RPP Berdasarkan Aspek yang Dinilai

\begin{tabular}{|c|c|c|c|}
\hline Aspek yang Dinilai & $\begin{array}{l}\text { Skor } \\
\text { Maks }\end{array}$ & Skor & Kriteria \\
\hline $\begin{array}{l}\text { Identitas Mata } \\
\text { Pelajaran }\end{array}$ & 40 & 38 & $\begin{array}{c}\text { Sangat } \\
\text { Valid }\end{array}$ \\
\hline $\begin{array}{l}\text { Rumusan/Tujuan } \\
\text { Indikator }\end{array}$ & 50 & 47 & $\begin{array}{l}\text { Sangat } \\
\text { Valid }\end{array}$ \\
\hline Pemilihan Materi & 50 & 43 & $\begin{array}{c}\text { Sangat } \\
\text { Valid }\end{array}$ \\
\hline $\begin{array}{c}\text { Metode } \\
\text { Pembelajaran }\end{array}$ & 40 & 38 & $\begin{array}{c}\text { Sangat } \\
\text { Valid }\end{array}$ \\
\hline $\begin{array}{c}\text { Kegiatan } \\
\text { Pembelajaran }\end{array}$ & 60 & 51 & $\begin{array}{c}\text { Sangat } \\
\text { Valid }\end{array}$ \\
\hline Penutup & 10 & 8 & Valid \\
\hline $\begin{array}{c}\text { Pemilihan Sumber } \\
\text { Belajar/Media } \\
\text { Pembelajaran }\end{array}$ & 70 & 58 & $\begin{array}{l}\text { Sangat } \\
\text { Valid }\end{array}$ \\
\hline $\begin{array}{l}\text { Penilaian Hasil } \\
\text { Belajar }\end{array}$ & 50 & 42 & $\begin{array}{l}\text { Sangat } \\
\text { Valid }\end{array}$ \\
\hline Kebahasaan & 30 & 24 & Valid \\
\hline
\end{tabular}


Hasil analisis data penilaian validator terhadap LKS berdasarkan aspek-aspeknya menunjukkan bahwa untuk aspek prosedur kegiatan dan pertanyaan (soal) mempunyai kriteria valid, sedangkan ketujuh aspek yang lain mempunyai kriteria sangat valid. Secara terperinci penilaian validator terhadap LKS hasil pengembangan untuk masing-masing aspek disajikan dalam Tabel 4 berikut ini.

Tabel 4. Proses Validasi LKS Berdasarkan Aspek yang Dinilai

\begin{tabular}{|c|c|c|c|}
\hline Aspek yang Dinilai & $\begin{array}{l}\text { Skor } \\
\text { Maks }\end{array}$ & Skor & Kriteria \\
\hline $\begin{array}{l}\text { Identitas dan } \\
\text { Petunjuk }\end{array}$ & 20 & 20 & $\begin{array}{l}\text { Sangat } \\
\text { Valid }\end{array}$ \\
\hline Alokasi Waktu & 20 & 19 & $\begin{array}{c}\text { Sangat } \\
\text { Valid }\end{array}$ \\
\hline $\begin{array}{c}\text { Tujuan } \\
\text { Pembelajaran }\end{array}$ & 20 & 19 & $\begin{array}{c}\text { Sangat } \\
\text { Valid }\end{array}$ \\
\hline Alat dan Bahan & 20 & 17 & $\begin{array}{l}\text { Sangat } \\
\text { Valid }\end{array}$ \\
\hline Prosedur Kegiatan & 30 & 24 & Valid \\
\hline Tampilan & 30 & 27 & $\begin{array}{l}\text { Sangat } \\
\text { Valid }\end{array}$ \\
\hline Bahasa & 40 & 34 & $\begin{array}{l}\text { Sangat } \\
\text { Valid }\end{array}$ \\
\hline Isi & 110 & 94 & $\begin{array}{l}\text { Sangat } \\
\text { Valid }\end{array}$ \\
\hline Pertanyaan (Soal) & 30 & 24 & Valid \\
\hline
\end{tabular}

Selanjutnya dilakukan analisis data pada media berbantuan komputer. Menurut hasil validasi ahli media komputer yang dikembangkan mempunyai kriteria sangat valid. Hasil perincian per aspek untuk penilaian media dijelaskan dalam Tabel 5 berikut.

Tabel 5. Proses Validasi Media Berdasarkan Aspek yang Dinilai

\begin{tabular}{cccc}
\hline $\begin{array}{c}\text { Aspek yang } \\
\text { Dinilai }\end{array}$ & $\begin{array}{c}\text { Skor } \\
\text { Maks }\end{array}$ & Skor & Kriteria \\
\hline Penampilan & 170 & 165 & $\begin{array}{c}\text { Sangat } \\
\text { Valid }\end{array}$ \\
Interaktifitas & 20 & 18 & $\begin{array}{c}\text { Sangat } \\
\text { Valid }\end{array}$ \\
\hline
\end{tabular}

Analisis terhadap instrumen sebagai pelengkap dalam penelitian ini digunakan untuk menentukan efektif tidaknya perangkat pembelajaran hasil pengembangan. Validasi instrumen tes akhir oleh validator dilakukan per item soal dan hasilnya adalah bahwa setiap item soal mempunyai kriteria valid atau sangat valid. Hasil validasi ini selanjutnya akan dilihat secara menyeluruh berdasarkan penilaian validator menurut aspek-aspek yang ada, yaitu aspek kisikisi, soal, kunci jawaban dan pedoman penskoran. Secara lebih jelas rincian hasil validasi ahli disajikan dalam Tabel 6.

Tabel 6. Proses Validasi Instrumen Tes Akhir Berdasarkan Aspek yang Dinilai

\begin{tabular}{cccc}
\hline Aspek yang Dinilai & $\begin{array}{c}\text { Skor } \\
\text { Maks }\end{array}$ & Skor & Kriteria \\
\hline Kisi-kisi & 64 & 64 & $\begin{array}{c}\text { Sangat } \\
\text { Valid }\end{array}$ \\
Soal & 192 & 160 & $\begin{array}{c}\text { Sangat } \\
\text { Valid } \\
\text { Sangat } \\
\text { Valid }\end{array}$ \\
$\begin{array}{c}\text { Kunci Jawaban dan } \\
\text { Pedoman Penskoran }\end{array}$ & 64 & 64 & \\
\hline
\end{tabular}

Hasil penilaian validator terhadap instrumen mathematics self efficacy adalah sangat valid dan hasil penilaian tersebut secara terpisah diperinci menurut dua aspek. Kedua aspek tersebut adalah aspek isi dan bahasa yang lebih jelasnya disajikan dalam Tabel 7.

Tabel 7. Proses Validasi Instrumen MSE Berdasarkan Aspek yang Dinilai

\begin{tabular}{cccc}
\hline $\begin{array}{c}\text { Aspek yang } \\
\text { Dinilai }\end{array}$ & $\begin{array}{c}\text { Skor } \\
\text { Maks }\end{array}$ & Skor & Kriteria \\
\hline Isi & 20 & 17 & Sangat Valid \\
Bahasa & 30 & 28 & Sangat Valid \\
\hline
\end{tabular}

Analisis Data Hasil Uji Coba Kelompok Kecil

Penilaian guru terhadap silabus, RPP, LKS, dan media pada uji coba kelompok kecil adalah mempunyai kriteria sangat praktis. Penilaian terhadap silabus oleh penilai 1 dan penilai 2 secara kumulatif mencapai skor 66 dari maksimal skor 70, sehingga silabus hasil pengembangan dalam penelitian ini masuk pada kriteria sangat praktis.

Penilaian RPP yang dikembangkan oleh penilai 1 memberikan skor maksimal untuk semua indikator yang ada. Oleh karena itu, penilai 1 tidak memberikan saran revisi untuk RPP pada lembar yang disediakan. Menurut penilai 1, RPP yang dikembangkan telah memenuhi kriteria penyusunan RPP yang baik dan layak digunakan.

Berbeda dengan penilai 1, hasil penilaian RPP oleh penilai 2 untuk 7 indikator yang ada adalah skor 4 (baik) untuk 4 indikator dan skor 5 (sangat baik) untuk 3 indikator yang lain. Penilaian terhadap LKS diperinci dalam 7 indikator. Penilai 1 memberikan skor 5 (sangat baik) untuk 6 indikator, sedangkan indikator 
mengenai kejelasan bahasa yang digunakan diberikan skor 4 (baik). Meskipun hampir semua indikator diberi nilai maksimal oleh penilai 1 , namun di lembar saran penilai 1 menuliskan saran berupa masukan untuk memberikan beberapa langkah menjawab pada LKS. Tentu saja masukan ini dipertimbangkan lagi oleh peneliti bersama dengan penilai 1 dan penilai 2 .

Penilaian terhadap media oleh penilai 1 maupun penilai 2 pada dasarnya sudah baik, yaitu mencapai skor kumulatif 56 dari skor maksimal 60. Kriteria penilaian untuk media pada uji coba kelompok kecil adalah sangat praktis. Baik penilai 1 maupun penilai 2 tidak memberikan saran terhadap media yang dikembangkan, sehingga media siap digunakan untuk uji coba lapangan yang akan diujikan di kelas coba tanpa direvisi terlebih dahulu.

Analisis mengenai hasil penilaian oleh siswa sebanyak 9 orang siswa dengan kemampuan yang beragam sebagai sampel dalam kegiatan uji coba kelompok kecil dilakukan untuk mengetahui kepraktisan perangkat pembelajaran hasil pengembangan. Setelah melaksanakan uji coba kelompok kecil, siswa diminta untuk mengisi lembar penilaian siswa.

Penilaian terhadap kepraktisan perangkat pembelajaran juga dilakukan berdasarkan hasil observasi kegiatan guru dan siswa. Observasi dilaksanakan oleh seorang guru matematika. Kegiatan guru mempunyai skor total 15 dari 15 deskriptor yang ada. Hal ini berarti bahwa guru mengajar sesuai dengan langkah-langkah yang diharapkan dalam perencanaan pembelajaran dan termasuk dalam kriteria sangat praktis. Sedangkan pada kegiatan siswa hanya tampak 5 deskriptor dari 8 deskriptor yang ada dan termasuk dalam kriteria praktis. Tiga deskriptor yang belum tampak dilakukan siswa adalah menjawab pertanyaan guru, memperhatikan siswa lain dalam satu kelompok yang sedang memberikan penjelasan, dan bertanya kepada guru.

\section{Analisis Data Hasil Uji Coba Lapangan}

Pada uji coba lapangan, hampir keseluruhan aspek penilaian guru pada uji coba lapangan mencapai skor yang mendekati skor maksimal dan termasuk dalam kriteria sangat praktis. Penilaian terhadap silabus mencapai skor kumulatif untuk kedua penilai sebesar 67. Sedangkan RPP dan LKS mencapai skor yang sama yaitu 68. Hasil penilaian RPP dan LKS oleh penilai 1 adalah dengan skor maksimal 5 (sangat baik) untuk kedelapan indikator penilaian yang ada. Penilai 2 memberikan skor 4 (baik) pada RPP untuk indikator ketepatan bahasa dan kecukupan waktu untuk setiap tahapan pembelajaran, demikian pula untuk LKS pada indikator bahasa dan kemenarikan penampilan LKS diberikan skor 4 (baik).

Penilaian siswa terhadap LKS dan instrumen tes akhir adalah praktis digunakan di lapangan. Sedangkan media pembelajaran yang dikembangkan mempunyai kriteria sangat praktis. Penilaian LKS secara terperinci untuk masing-masing indikator adalah skor rata-rata 3,63 untuk indikator pertama yaitu berkaitan dengan kejelasan materi dalam LKS. Indikator kedua tentang kejelasan bahasa memperoleh skor rata-rata 4,07 dengan kategori baik. Kemenarikan penampilan LKS dengan skor rata-rata paling kecil, yaitu 3,60 namun masih dalam kategori cukup baik. Keruntutan materi dalam LKS mencapai skor rata-rata 3,63.

Penilaian terhadap instrumen tes akhir secara keseluruhan termasuk dalam kriteria praktis, dengan rincian skor rata-rata per indikator berturut-turut adalah 4,07; 3,87; 3,90; dan 3,43 . Skor rata-rata terendah adalah untuk indikator keempat yaitu mengenai kejelasan bahasa yang digunakan.

Skor rata-rata untuk penilaian terhadap media relatif cukup tinggi jika dibandingkan dengan penilaian siswa terhadap LKS dan instrumen tes akhir. Indikator penyajian isi media mencapai skor rata-rata 3,93. Sedangkan untuk ketiga indikator yang lain mencapai skor rata-rata lebih dari 4. Jadi secara keseluruhan, media pembelajaran yang dikembangkan sudah baik dan praktis dalam penggunaannya.

Hasil observasi kegiatan guru mempunyai kriteria sangat praktis karena hampir keseluruhan deskriptor yang ada tampak dilakukan oleh guru pada saat mengajar. Sedangkan untuk kegiatan siswa ada beberapa desktiptor yang masih belum tampak yaitu pada pertemuan pertama dan pertemuan ketiga. Pada pertemuan pertama, deskriptor yang belum tampak adalah memperhatikan penjelasan guru. Pada pertemuan ketiga, deskriptor yang tidak tampak adalah siswa bertanya kepada guru.

\section{Revisi Produk}

\section{Revisi Silabus}

Revisi silabus yang dilakukan adalah perbaikan indikator dan perbaikan contoh instrumen yaitu berupa perbaikan pada kesalahan penulisan soal. 


\section{Revisi RPP}

Masukan dan saran perbaikan yang diberikan oleh validator terhadap draf 1 produk pengembangan RPP antara lain perbaikan pada indikator, perbaikan pada materi ajar, dan perbaikan pada soal pekerjaan rumah.

\section{Revisi LKS}

Revisi LKS berupa perbaikan indikator, perbaikan langkah-langkah kerja pada bagian kegiatan menemukan teorema Pythagoras, dan perbaikan pada permasalahan yang disajikan yaitu lebih banyak menyajikan masalah kontekstual.

\section{Revisi Media Pembelajaran}

Beberapa saran perbaikan untuk media pembelajaran berbantuan komputer adalah menambahkan logo UNY pada setiap slide, perbaikan pada gambar, dan perbaikan pada beberapa kesalahan penulisan.

\section{Kajian Produk Akhir}

Pengembangan perangkat pembelajaran dalam tesis ini telah dilakukan melalui beberapa tahapan, yaitu pendefinisian, perancangan, pengembangan, dan penyebaran. Berdasarkan hasil validasi ahli, uji coba kelompok kecil, uji coba lapangan, dan perbaikan-perbaikan, serta analisis data yang dilakukan dapat diketahui bahwa perangkat pembelajaran yang dikembangkan telah memenuhi kriteria valid, praktis, dan efektif ditinjau dari prestasi belajar siswa dan mathematics self- efficacy.

Kevalidan

Penelitian pengembangan perangkat pembelajaran dinyatakan valid jika keseluruhan produk hasil pengembangan memenuhi kriteria kevalidan yang telah ditetapkan. Kriteria kevalidan ditentukan berdasarkan hasil penilaian ahli sebagai validator yang terdiri dari dua orang dosen Pendidikan Matematika UNY. Penilaian dilakukan pada silabus, RPP, LKS, dan media. Hasil validasi dan analisis data menunjukkan bahwa keempat perangkat pembelajaran yang telah dikembangkan memiliki kriteria sangat valid.

\section{Kepraktisan}

Kriteria kepraktisan ditentukan berdasarkan penilaian guru dan penilaian siswa, serta data hasil observasi kegiatan guru dan kegiatan siswa pada uji coba lapangan. Berdasarkan hasil penilaian guru, perangkat pembelajaran yang dikembangkan mempunyai kriteria sangat praktis. Dua orang guru matematika di SMP Negeri 2 Banyubiru memberikan penilaian kepraktisan terhadap silabus, RPP, LKS, dan media berbantuan komputer yang digunakan untuk mengajar dalam penelitian ini.

Penilaian oleh siswa terhadap perangkat pembelajaran yang dikembangkan meliputi penilaian LKS dan media. Selain itu, siswa juga memberikan penilaian terhadap instrumen tes akhir sebagai pelengkap dalam penelitian ini. Hasilnya 9 siswa dari 30 siswa kelas VIIIE yang menjadi subjek coba menilai bahwa perangkat pembelajaran yang dikembangkan mempunyai kriteria sangat praktis, sedangkan 21 siswa yang lain menyebutkan bahwa perangkat pembelajaran yang dikembangkan adalah praktis.

Hasil observasi kegiatan guru dalam pembelajaran, menunjukkan bahwa pembelajaran menggunakan perangkat yang dikembangkan adalah sangat praktis untuk seluruh pertemuan. Sedangkan untuk kegiatan siswa mempunyai kriteria praktis dan sangat praktis. Berdasarkan ketiga data mengenai penilaian guru, penilaian siswa, dan observasi kegiatan pembelajaran di lapangan, dapat dikatakan bahwa perangkat pengembangan yang dikembangkan memenuhi kriteria kepraktisan.

\section{Keefektifan}

\section{Keefektifan Ditinjau dari Prestasi Belajar Siswa}

Kriteria keefektifan ditinjau dari prestasi belajar siswa yang telah ditentukan dalam pencapaian keberhasilan penelitian pengembangan ini adalah jika banyaknya siswa yang memperoleh nilai tes akhir melebihi KKM sebesar 75\%. Hasil dari tes akhir yang dilaksanakan menunjukkan bahwa siswa yang memperoleh nilai tes akhir melampaui KKM adalah sebanyak 23 siswa. Hal ini berarti $76,67 \%$ siswa telah memperoleh nilai tes akhir melebihi KKM, sehingga dapat dikatakan bahwa penelitian pengembangan ini adalah efektif ditinjau dari prestasi belajar siswa.

\section{Keefektifan Ditinjau dari Skor Mathematics Self-Efficacy}

Kriteria keefektifan ditinjau dari skor mathematics sel-efficacy siswa yang telah ditentukan dalam pencapaian keberhasilan penelitian pengembangan ini adalah jika banyaknya siswa yang mempunyai skor mathematics self-efficacy dengan kategori tinggi atau sangat tinggi adalah sebanyak $75 \%$. Hasil pengisian kuesioner 
mathematics self-efficacy menunjukkan bahwa siswa yang memiliki skor mathematics selfefficacy dengan kriteria sangat tinggi adalah sebanyak 2 siswa. Sebanyak 23 siswa yang lain memiliki skor mathematics self-efficacy dengan kriteria tinggi dan 2 siswa sisanya memiliki skor mathematics self-efficacy dengan kriteria sedang. Hal ini berarti 83,34\% siswa telah memiliki skor mathematics self-efficacy pada kriteria tinggi atau sangat tinggi, sehingga dapat dikatakan bahwa penelitian pengembangan ini adalah efektif ditinjau dari skor mathematics selfefficacy siswa.

\section{Keterbatasan Penelitian}

Pelaksanaan pembelajaran harus dilakukan di dalam ruang laboratorium komputer, sehingga dalam uji coba lapangan perlu menyesuaikan jadwal pemakaian laboratorium. Di SMP Negeri 2 Banyubiru telah diterapkan sistem moving class dan lebih khusus lagi untuk pembelajaran TIK selalu dilaksanakan di ruang laboratorium komputer, baik pelajaran teori maupun praktik. Pada saat dilakukan uji coba lapangan pembelajaran TIK yang biasanya dilaksanakan di ruang laboratorium komputer dipindahkan ke ruang kelas untuk sementara waktu. Hal ini tentu saja menjadi suatu permasalahan yang perlu dipertimbangkan ketika menerapkan pembelajaran berbantuan komputer hasil pengembangan ini.

Permasalahan yang lain adalah semula penelitian ini dirancang untuk setiap anak menggunakan satu unit komputer, namun karena dari 32 unit komputer yang ada hanya 28 unit komputer yang bisa digunakan, maka ada empat siswa yang menggunakan komputer secara bersama-sama, yaitu satu komputer untuk dua siswa.

Siswa diharapkan dapat menggunakan media komputer yang telah dikembangkan di rumah masing-masing, namun demikian hanya ada beberapa siswa yang dapat melakukannya berkaitan dengan tidak tersedianya perangkat komputer atau laptop di rumah siswa. Oleh karena itu, latihan-latihan soal yang sedianya diharapkan dapat dikerjakan siswa di rumah belum dapat diselesaikan secara menyeluruh di sekolah karena waktu pembelajaran di sekolah digunakan untuk mengerjakan LKS saja.

Tahap keempat dalam penelitian ini belum dapat dilaksanakan dengan sepenuhnya. Hal ini dikarenakan keterbatasan peneliti dalam menyebarkan perangkat pembelajaran yang telah dikembangkan ini pada kelas-kelas atau sekolah yang lain.

\section{SIMPULAN DAN SARAN}

\section{Simpulan}

Berdasarkan hasil penelitian dan pembahasan diperoleh simpulan sebagai berikut: (1) Hasil pengembangan perangkat pembelajaran dalam penelitian ini berupa silabus, RPP, LKS, dan media pembelajaran berbantuan komputer telah divalidasi ahli dan hasilnya sangat valid. (2) Kriteria kepraktisan perangkat pembelajaran hasil pengembangan yang berupa silabus, RPP, LKS, dan media pembelajaran berbantuan komputer dalam penelitian ini telah tercapai, yaitu melalui hasil analisis data penilaian guru, lembar observasi kegiatan guru dan siswa, serta data penilaian siswa. (3) Perangkat pembelajaran hasil pengembangan yang berupa silabus, RPP, LKS, dan media pembelajaran berbantuan komputer dalam penelitian ini telah efektif ditinjau dari prestasi belajar siswa, yaitu 76,67\% siswa memperoleh nilai tes akhir melampaui KKM dan sebanyak 83,34\% memiliki skor mathematics self efficacy minimal pada kategori tinggi.

\section{Saran}

Berdasarkan hasil penelitian dan simpulan, beberapa saran yang perlu dipertimbangkan untuk peningkatan kualitas pembelajaran matematika, yaitu sebagai berikut: (1) Guru perlu melakukan pembiasaan dalam pembelajaran agar siswa mampu menyampaikan pendapat mereka, menanyakan hal-hal yang belum jelas, dan menjawab pertanyaan-pertanyaan yang disampaikan oleh guru. Hal ini dikarenakan dalam pelakasanaan uji coba kelompok kecil maupun uji coba lapangan, siswa masih belum begitu aktif berbicara di depan kelas. (2) Dalam pembelajaran guru perlu menekankan materi penerapan teorema Pythagoras yang berkaitan dengan bangun segi empat terutama pada bangun belah ketupat dan jajar genjang. Guru sebaiknya melakukan kegiatan yang dapat mengingatkan kembali mengenai konsep penting dalam bangun datar misalnya masalah yang berkaitang dengan unsur-unsur bangun datar tertentu, konsep keliling, maupun luas.

\section{DAFTAR PUSTAKA}

Anjum, R. (2006). The impact of self-efficacy on mathematics achievement of primary school children. Pakistan Journal of 
Psychological Reasearch: Winter, 21, 3/4; ProQuest Research Library.

Bandura, A. (1995). Exercise of personal and collective efficacy in changing societies. In A. Bandura (Ed.), Self-efficacy in changing societies. New York: Cambridge University Press.

Bandura, A. (1977). Self-efficacy: Toward a unifiying theory of behavioral change. Psychological Review. Vol. 34, No. 2, 191-215. Error! Hyperlink reference not valid.

Crawford, M. L. (2001). Teaching contextually: Research, rationale, and techniques for improving student motivation and achievement in mathematics and science. Waco, Texas: CCI Publishing, Inc.

Johnson, E. B. (2010). CTL Contextual teaching learning: Menjadikan kegiat-an belajarmengajar mengasyikkan dan bermakna. Cetakan Pertama. (Ter-jemahan Ibnu Setiawan). Bandung: Kaifa. (Buku asli diterbitkan tahun 2009).

Liu, X., \& Koirala, H. (2009). The effect of mathematics self-efficacy on mathematics achievement of high school students. In: Proceeding of the NERA (Northeastern Educational Research Association) Conference 2009. Tersedia di Error! Hyperlink reference not valid. diakses tanggal 29 Mei 2013).

Masnur Muslich. (2008). KTSP pembelajaran berbasis kompetensi dan kontekstual: Panduan bagi guru, kepala sekolah, dan pengawas sekolah. Cetakan ke-4. Jakarta: Bumi Aksara.

Moore, K. D. (2009). Effective instructional strategies: from theory to practice. London: Sage Publication, Inc.

Ormrod, J. E. (2003). Educational psychology: Developing learners. (4 ${ }^{\text {th }}$ ed.). Upper Saddle River,NJ: Merril Prentice Hall.
Sengul, S. (2011). Effects of concept cartoons on mathematics self-efficacy of 7 th grade students. Educational Sciences: Theory \& Practice-11(4). Auntumnpage 2305-2313.

Skemp, R. R. (1971). The psychology of learning mathematics. Victoria, Australia: Penguin Books Ltd.

Souders, J. (1999). Contextually based learning: Fad or proven practice. American Youth Policy Forum. Washington, D. C. Diungguh dari http://www.aypf.org/forumbriefs/1999/t b070999.htm. Diungguh tanggal $20 \mathrm{Mei}$ 2013.

Sunnetha, E., Sambasiva Rao, R., \& Bhaskara Rao, D. (2011). Methods of teaching mathematics. New Delhi: Discovery Publishing House.

Tait, S. L. (2008). Self-efficacy in mathematics: Affective, cognitive, and conative domains of functioning. Proceedings of the 31st Annual Conference of the Mathematics Education Research Group of Australasia. Merga Inc.

Tamuri, H. (2005). Permasalahan pelajar-pelajar fakir miskin di daerah Sabak Bernam. Jurnal Pendidikan, Vol 30. 21-33.

Thiagarajan, S., Semmel, D. S., \& Semmel, M. I. (1974). Instructional development for training teachers of exceptional children, a source book. Blomington, Indiana: Indiana University.

Margolis, H., \& McCabe, P. P. (2006). Improving self-efficacy and motivation: What to do, what to say. Intervention in School and Clinic. 41, 4; ProQuest. pg. 218-227.

Zimmermann, M., Bescherer, C., \& Spannagel, C. (2011). A questionaire for surveying mathematics self-efficacy expectations of future teachers. Article of German Federal Ministry of Education and Research. 